\title{
Development of Spectrophotometric Method for the Determination of Azoxystrobin Fungicide after Derivatization
}

Kafeel Ahmad Khan*, Hussain Gulab and Farzana Haider

Department of Chemistry, Bacha Khan University, Charsadda, KPK, Pakistan

\begin{abstract}
A UV-Visible spectrophotometric method has been developed for the determination of azoxystrobin fungicide. Complexation reaction of the azoxystrobin fungicide was carried out with the Ferric (III) chloride in presence of hydroxylamine hydrochloride in alkaline medium resulting in a reddish-brown color complex. The absorbance of the complex was measured at $513 \mathrm{~nm}$ using UV-visible spectrophotometer. Different parameters affecting the derivatization reactions were carefully studied and optimized. Beer's law was obeyed in the concentration range of $1-12 \mu \mathrm{mL}^{-1}$. The molar absorptivity, limit of detection and limit of quantification were calculated and found to be $4.3 \times 10^{-4} \mathrm{~L} \mathrm{~mol}^{-1}$ $\mathrm{cm}^{-1}, 0.38 \mu \mathrm{g} \mathrm{mL}^{-1}$ and $1.26 \mu \mathrm{g} \mathrm{mL}^{-1}$ respectively. Similarly, the mean limit of detection and limit of quantification were calculated for residue determination and were found to be $3.8 \pm 1.02 \mu \mathrm{g} \mathrm{mL}^{-1}$ and $3.98 \pm 1.4 \mu \mathrm{g} \mathrm{mL}^{-1}$, respectively. The proposed method was successfully applied for the determination of azoxystrobin in pure form and in commercial formulations.
\end{abstract}

Keywords: Hydroxamic acid; Iron (III); UV-visible spectrophotometer; Beer-Lambert's law; Limit of detection (LOD); Limit of quantification (LOQ)

\section{Introduction}

Fungicides play vital role in prevention of growth of fungi. Fungi are capable to damage cultivation, which leads to loss in crop yield, quality and their economic value [1]. Fungicides are able to damage fungal cell membranes or interfere with energy production within fungal cells [2]. Fungicides have controlled to large extant the pest attacks on agriculture. Every new discovery in the field of agriculture enhanced the day to day requirements of farmers which fulfill the demands of era. The discovery of these fungicides has attenuated the development of resistance against the specific fungi [3]. The top quality crops are day to day need for the existence of human being. Many micro-organisms spoil crop which leads to worldwide food shortage. Among these microorganisms fungi play a critical role in decaying crops [4]. Azoxystrobin is a fungicide commonly used in agriculture. It is used as an active agent protecting plants and fruit/vegetables from fungal diseases [3].

Azoxystrobin [methyl (E)-2-2-[6-(2-cyanophenoxy)-pyrimidin4-yloxy] phenyl-3-thoxyacrilate] is a strobilurin fungicide $[3,4]$ The azoxystrobin has increased the persistence of disease control, an effect that leads to prolonged green leaf retention and extended grain fill compared to traditional triazole fungicides [3,5]. Due to its fungicidal action, the inhibition of mitochondrial respiration in fungi occurs and stopping their energy supply [2,5]. Azoxystrobin is more effective on fruits, vegetables, rice and cereals. Azoxystrobin is evenly distributed through the vascular tissues of plant leaf and transported to the xylem thus protects from fungal pathogens [6]. Various studies on azoxystrobin have been carried out using High performance liquid chromatography [6-12], Gas chromatography [13,14], gas chromatography-mass spectrometry (GC-MS) [15-17], and gas chromatography in combination with electron capture detection [18]. Moreover, liquid chromatography-tandem mass spectrometry was used to determine azoxystrobin residue $[19,20]$. The literature reveals that no work has been done on UV-visible spectrophotometric determination of azoxystrobin fungicide. Thus the aim of the present study is to develop a simple cost effective and easily accessible spectrophotometric method for the analysis of azoxystrobin in standards and commercial formulation.

\section{Materials and Methods}

\section{Instrument}

The samples were analyzed using UV-Visible spectrophotometer (Shimadzu, UV-1800, ENG 240 V).

\section{Reagents}

Hydroxylamine hydrochloride was purchased from Fisher Chemicals Laborites, UK. Ethanol, Sodium hydroxide, Sulphuric acid and Hydrochloric acid were purchased from BDH, Ana R, England. The Ferric chloride and methanol were purchased from Sigma-Aldrich, Germany. Commercially formulated azoxystrobin containing 18.2\% active ingredient was purchased from the local market. The standard azoxystrobin was purchased from Sigma-Aldrich, Germany. All the solutions used were stable at room temperature.

\section{Solutions}

i) Preparation of azoxystrobin standard solution: A standard stock solution of azoxystrobin $(300 \mu \mathrm{g} / 100 \mathrm{~mL})$ was prepared by dissolving $3 \times 10^{-4} \mathrm{~g}$ of azoxystrobin in $20 \mathrm{~mL}$ methanol and diluted with methanol up to $100 \mathrm{~mL}$.

ii) Preparation of hydroxylamine hydrochloride solution: A $0.25 \mathrm{~mol} / \mathrm{L}$ hydroxylamine hydrochloride solution was prepared by dissolving $1.75 \mathrm{~g}$ hydroxylamine hydrochloride in $30 \mathrm{~mL}$ of methanol and diluted with methanol up to $100 \mathrm{~mL}$ to get $0.25 \mathrm{M}$ concentrated solution.

*Corresponding author: Khan KA, Department of Chemistry, Bacha Khan University, Charsadda, KPK, Pakistan, Tel: +92 91 6540117; Fax: 92-91-6541160; E-mail:kafeelaps@gmail.com

Received: March 11, 2018; Accepted: April 24, 2018; Published May 01, 2018

Citation: Khan KA, Gulab H, Haider F (2018) Development of Spectrophotometric Method for the Determination of Azoxystrobin Fungicide after Derivatization. Biochem Anal Biochem 7: 353. doi: 10.4172/2161-1009.1000353

Copyright: (C) 2018 Khan KA, et al. This is an open-access article distributed under the terms of the Creative Commons Attribution License, which permits unrestricted use, distribution, and reproduction in any medium, provided the original author and source are credited. 
Citation: Khan KA, Gulab H, Haider F (2018) Development of Spectrophotometric Method for the Determination of Azoxystrobin Fungicide after Derivatization. Biochem Anal Biochem 7: 353. doi: 10.4172/2161-1009.1000353

Page 2 of 6

iii) Sodium hydroxide and hydrochloric acid solutions: A $5 \mathrm{~mol} / \mathrm{L}$ sodium hydroxide solution was prepared by dissolving $20 \mathrm{~g}$ of sodium hydroxide in $20 \mathrm{~mL}$ distilled water and diluted with distilled water up to $100 \mathrm{~mL}$ to get $5 \mathrm{M}$ concentrated solution. A $2 \mathrm{~mol} / \mathrm{L}$ hydrochloric acid solution was prepared by dissolving $6.13 \mathrm{~mL}$ of $\mathrm{HCl}$ in $100 \mathrm{~mL}$ distilled water.

iv) Preparation of Ferric chloride solution: A 5\% Ferric chloride solution was prepared by dissolving $5 \mathrm{~g}$ of $\mathrm{FeCl}_{3}$ in $30 \mathrm{~mL}$ methanol and then diluted up to $100 \mathrm{~mL}$ with methanol. Furthermore, $2-3 \mathrm{~mL}$ of concentrated sulphuric acid were added to this solution in order to maintain all the iron atoms in Ferric (III) oxidation state.

\section{Procedure}

A $3 \mathrm{~mL}$ azoxystrobin solution was taken from the standard stock solution of azoxystrobin $(300 \mu \mathrm{g} / \mathrm{mL})$ and $1.0 \mathrm{~mL}$ of $0.25 \mathrm{~mol} / \mathrm{L}$ hydroxylamine hydrochloride solution was added to it. Then $0.4 \mathrm{~mL}$ of $5 \mathrm{M}$ solution of $\mathrm{NaOH}$ solution was added to this mixture and equilibrated for 2 minutes. The medium was acidified by adding 2 $\mathrm{mL}$ of $2 \mathrm{~mol} / \mathrm{L}$ hydrochloric acid followed by the addition of $2 \mathrm{~mL}$ ethanol. A $0.4 \mathrm{~mL}$ of $\mathrm{FeCl}_{3}$ (5\%) solution was added to this mixture and equilibrated for 2 minutes to allow the reaction to complete. The resulting solution having reddish-brown color due to complex formation was transferred to a titration flask and then diluted with 10 $\mathrm{mL}$ of ethanol. Absorbance of this colored complex was measured at $513 \mathrm{~nm}$. All the solutions were stored in pyrex glass vessels.

\section{Proposed reaction}

The azoxystrobin reacts with hydroxyl amine hydrochloride to form hydroxamic acid by replacing the ester group of azoxystrobin. The azoxystrobin has a terminal ester group just like propionate which can be easily converted into hydroxyl propanamide (hydroxamic acid) with the help of hydroxyl amine hydrochloride in alkaline media. Then the hydroxamic acid was used as a ligand with iron (III) in acidic media resulting in a reddish brown color complex. The proposed mechanism is given as under;

Step 1: Formation of hydroxamic acid: The chemical structure of azoxystrobin contains a terminal ester group like "propanate" which can be easily converted into "hydroxyl propanamide (hydroxamic acid) with the help of hydroxylamine hydrochloride in alkaline media (Figure 1).

Step 2: Reaction of hydroxamic acid with Ferric (III) chloride: The hydroxamic acid was used as ligand with iron (III) in acidic media and resulted in a reddish brown colored iron (III) hydroxamate complex (Figure 2).

\section{Results and Discussion}

\section{maximum of azoxystrobin}

For investigation of $\lambda \max$, the coloured azoxystrobin solution was scanned within the range of $400-680 \mathrm{~nm}$. The curve shows the maximum absorbance of the azoxystrobin solution at $513 \mathrm{~nm}$. Various parameters were optimized for the spectrophometric method development at 513 nm wavelength (Figure 3).

\section{Optimization of various parameters for azoxystrobin com- plex}

Concentration optimization of hydroxyl amine hydrochloride: The concentration optimization of hydroxyl amine hydrochloride was carried out in a range of $0.05-0.45 \mathrm{~mol} / \mathrm{L}$ with a 0.02 interval. The complex was obtained by addition of $3 \mathrm{~mL}$ of $3 \mathrm{ppm}$ azoxystrobin and $0.4 \mathrm{~mL}$ of $5 \mathrm{M}$ solution of $\mathrm{NaOH}$. The mixture was equilibrated for 2 minutes. Then $2.0 \mathrm{~mL}$ of hydrochloric acid $\left(2.0 \mathrm{~mol} \mathrm{~L}^{-1}\right)$ was added to<smiles>COC=C(C(=O)OC)c1ccccc1Oc1cc(Oc2ccccc2C#N)ncn1</smiles>
$+\mathrm{NH}_{2} \mathrm{OH} \cdot \mathrm{HCl}$ $\mathrm{NaOH}$<smiles>N#Cc1ccccc1Oc1cc(Oc2ccccc2/C(=C\O)C(N)=O)ncn1</smiles>

Figure 1: Formation of hydroxamic acid<smiles>N#Cc1ccccc1Oc1cc(Oc2ccccc2/C(=C\O)C(=O)O)ncn1</smiles>

Hydroxamic acid

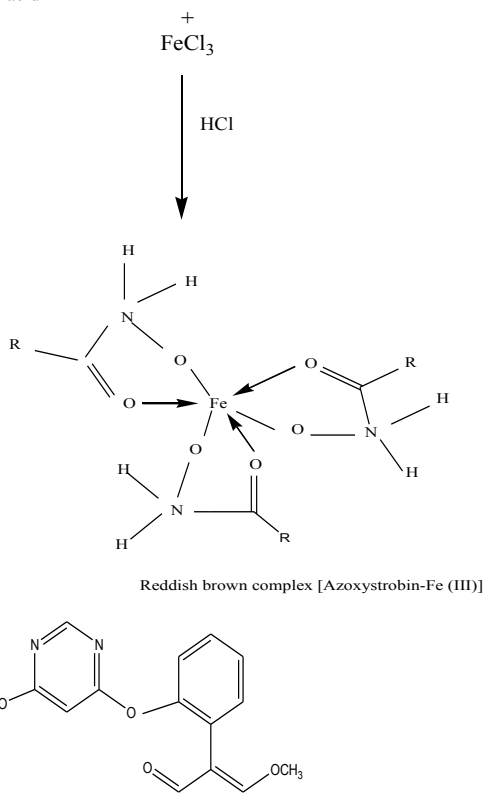

Figure 2: Reaction of hydroxamic acid with ferric (III) chloride. 
the mixture followed by the addition of $2.0 \mathrm{~mL}$ ethanol and finally, 0.4 $\mathrm{mL}$ of $\mathrm{FeCl}_{3}(5 \%)$ solution was added and its absorbance was measured at $513 \mathrm{~nm}$ (Figure 4).

Volume optimization of hydroxylamine hydrochloride: $3 \mathrm{~mL}$ azoxystrobin $(3 \mathrm{ppm})$ was treated with $1 \mathrm{~mL}$ of $5 \mathrm{M}$ solution of $\mathrm{NaOH}, 0.4 \mathrm{~mL}$ of $\mathrm{FeCl}_{3}$ (5\%) solution and various range of volumes (0.5-3.5 mL) of hydroxylamine hydrochloride $(0.25 \mathrm{~mol} / \mathrm{L})$ with an interval of $0.5 \mathrm{ml}$, the reaction was allowed for $2 \mathrm{~min}$. The absorbance of the resultant complex was measured at $513 \mathrm{~nm}$. The curve shows maximum absorption at $1 \mathrm{~mL}$ beyond which a decrease in absorbance can be observed (Figure 5).

\section{Concentration optimization of sodium hydroxide}

For concentration optimization of sodium hydroxide various concentrations of $\mathrm{NaOH}$ solution $(1-6 \mathrm{~mol} / \mathrm{L})$ were reacted with 3 $\mathrm{mL}(3 \mathrm{ppm})$ of azoxystrobin, $1 \mathrm{~mL}(0.25 \mathrm{~mol} / \mathrm{L})$ of hydroxylamine hydrochloride, $0.4 \mathrm{~mL}$ of $\mathrm{NaOH}$ solution and $0.4 \mathrm{~mL}$ of $\mathrm{FeCl}_{3}(5 \%)$ solution. The reaction was allowed for $2 \mathrm{~min}$ and absorbance of the product was measured at $513 \mathrm{~nm}$. At $2 \mathrm{~mol} / \mathrm{L}$ of $\mathrm{NaOH}$, maximum absorbance can be observed which could be the optimum concentration for maximum formation of the complex under given conditions (Figure 6).

Volume optimization of sodium hydroxide solution: $3 \mathrm{~mL}$ (3 ppm) of azoxystrobin was treated with $1 \mathrm{~mL}(0.25 \mathrm{~mol} / \mathrm{L})$ of hydroxylamine hydrochloride, $2 \mathrm{~mL}$ ethanol, $0.4 \mathrm{~mL}$ of $\mathrm{FeCl}_{3}(5 \%)$ solution and various volumes $(0.1-0.7 \mathrm{~mL})$ of $2 \mathrm{~mol} / \mathrm{L} \mathrm{NaOH}$ solution.

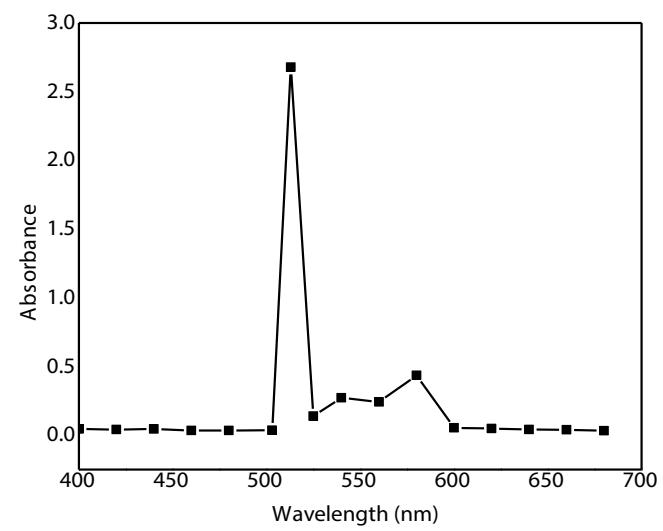

Figure 3: Determination of $\lambda \max$ for Iron-Azoxystrobin complex.

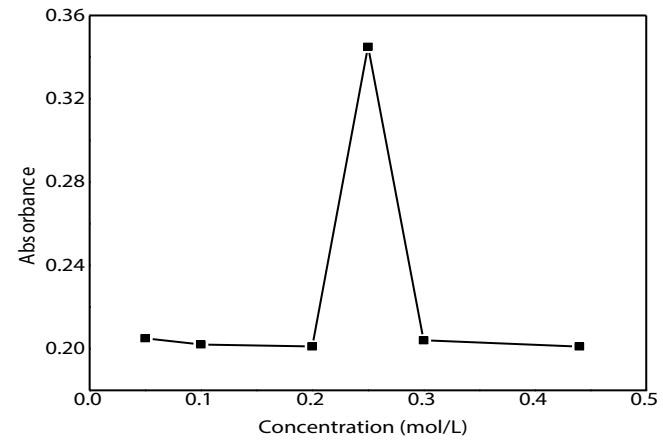

Figure 4: Effect of hydroxylamine hydrochloride concentration on Complex formation.
The reaction was allowed for $2 \mathrm{~min}$. The absorbance of the formed complex was measured at $513 \mathrm{~nm}$. The obtained absorbance data was plotted versus volume of $\mathrm{NaOH}$ solution. The maximum absorbance peak can be observed at $0.4 \mathrm{~mL} \mathrm{NaOH}$ volume which shows maximum formation of the complex at this volume (Figure 7).

\section{Concentration optimization of hydrochloric acid}

Various concentration (1-7 mol/L) of hydrochloric acid with an interval of $1 \mathrm{~mol} / \mathrm{L}$ were reacted with $3 \mathrm{~mL}$ of $3 \mathrm{ppm}$ azoxystrobin, 1 $\mathrm{mL}$ of $0.25 \mathrm{~mol} / \mathrm{L}$ of hydroxylamine hydrochloride, $0.4 \mathrm{~mL}$ of $\mathrm{NaOH}$ solution and $0.4 \mathrm{~mL}$ of $\mathrm{FeCl}_{3}$ (5\%) solution for $2 \mathrm{~min}$. The absorbance of the product was measured at $513 \mathrm{~nm}$. The maximum absorbance can be observed at $5 \mathrm{~mol} / \mathrm{L}$ concentration of hydrochloric acid (Figure 8).

Volume optimization of hydrochloric acid solution: A range of volume of hydrochloric acid solution i.e., 1-6 mL (with an interval of $1 \mathrm{~mL})$ was treated with $3 \mathrm{~mL}(3 \mathrm{ppm})$ of azoxystrobin, $1 \mathrm{~mL}(0.25$ $\mathrm{mol} / \mathrm{L}$ ) of hydroxylamine hydrochloride, $2 \mathrm{~mL}$ ethanol, $0.4 \mathrm{~mL}$ of $\mathrm{FeCl}_{3}$ (5\%) solution for $2 \mathrm{~min}$ and absorbance of the formed complex was measured at the $\Lambda_{\max }$, Absorbance of the complex product was plotted versus volume of hydrochloric acid solution. At $2 \mathrm{~mL}$ hydrochloric acid solution, the absorbance maximum can be observed and thus the $2 \mathrm{~mL}$ volume of $\mathrm{HCl}$ solution could be the optimum volume under the given conditions (Figure 9).

\section{Concentration optimization of Ferric (III) chloride solution}

Various concentration $(1-7 \mathrm{~mol} / \mathrm{L})$ of $\mathrm{FeCl}_{3}$ solution were treated with $3 \mathrm{~mL}$ ( $3 \mathrm{ppm})$ of azoxystrobin, $1 \mathrm{~mL}(0.25 \mathrm{~mol} / \mathrm{L})$ hydroxylamine hydrochloride and $0.4 \mathrm{ml}(2 \mathrm{~mol} / \mathrm{L})$ of $\mathrm{NaOH}$ solution and the reaction mixture was equilibrated for 2 minutes. Then $2 \mathrm{~mL}$ of hydrochloric acid ( $5 \mathrm{~mol} / \mathrm{L}$ ), $2 \mathrm{~mL}$ ethanol and $0.4 \mathrm{~mL}$ of $\mathrm{FeCl}_{3}$ were added. Absorbance of the formed complex was measured at $513 \mathrm{~nm}$. Figure 10 shows the curve of absorbance versus concentration of $\mathrm{FeCl}_{3}$ solution. At $5 \mathrm{~mol} / \mathrm{L}$ of $\mathrm{FeCl}_{3}$ concentration the maxium absorbance could be observed and thus this concentration could be the optimum concentration at the given reaction conditions (Figure 10).

Volume optimization of Ferric chloride solution: Various volumes $(0.1-0.7 \mathrm{~mL})$ of the $\mathrm{FeCl}_{3}$ solution were treated with $3 \mathrm{~mL}$ of (3 ppm) azoxystrobin, $1 \mathrm{~mL}$ of $(0.25 \mathrm{~mol} / \mathrm{L})$ of hydroxylamine hydrochloride and $0.4 \mathrm{~mL}$ of $(2 \mathrm{~mol} / \mathrm{L}) \mathrm{NaOH}$ solution for $2 \mathrm{~min}$ and absorbance of the product was measured at $K_{\max }$. The maximum absorbance was noted at $0.5 \mathrm{~mL}$ of $\mathrm{FeCl}_{3}$ solution, which could be the optimum volume of the reagent for complex formation (Figure 11).

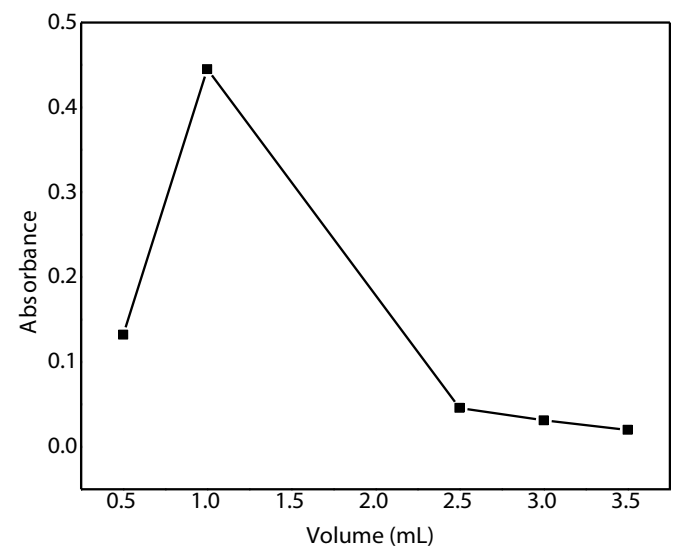

Figure 5: Volume optimization of hydroxylamine hydrochloride. 


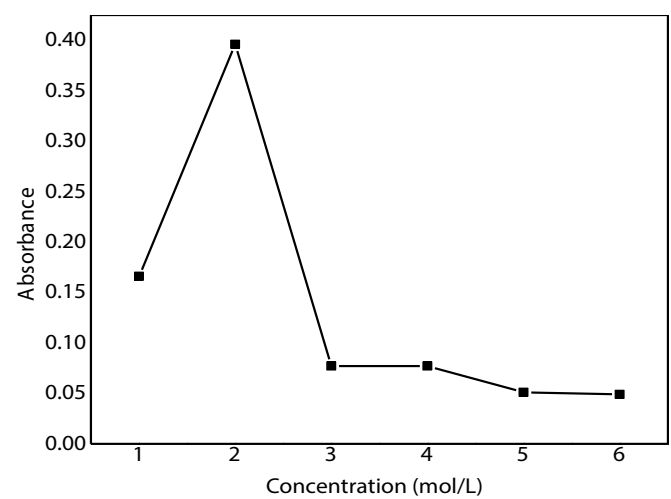

Figure 6: Effect of concentration of sodium hydroxide on complex formation.

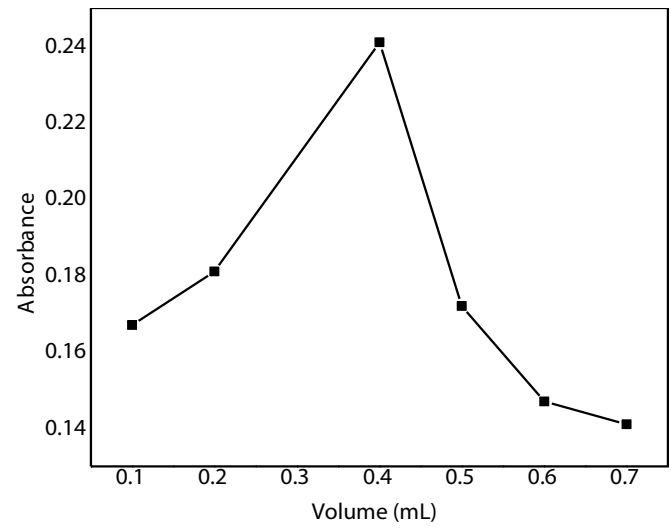

Figure 7: Effect of volume of sodium hydroxide solution on the Iron-azoxystrobin complex formation.

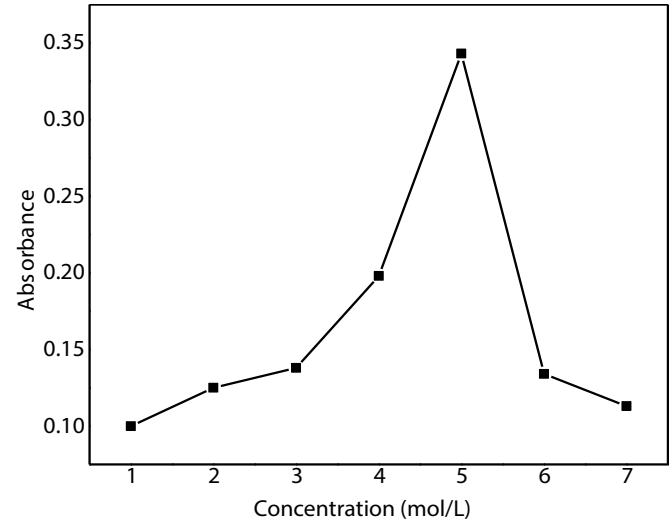

Figure 8: Effect of concentration of hydrochloric acid on Ironazoxystrobin complex formation.

\section{Reaction time optimization}

The reaction time was optimized for the maximum formation of the Iron-azoxystrobin complex. The Iron-azoxystrobin complex was formed by treating $3 \mathrm{~mL}$ of $3 \mathrm{ppm}$ standard solution of azoxystrobin, $1 \mathrm{~mL}$ of $(0.25 \mathrm{~mol} / \mathrm{L})$ hydroxylamine hydrochloride and $0.4 \mathrm{ml}$ of 2 $\mathrm{mol} / \mathrm{L} \mathrm{NaOH}$ solution and the reaction was allowed for different reaction times. Subsequently, $2 \mathrm{~mL}$ of $5 \mathrm{~mol} / \mathrm{L}$ hydrochloric acid, 2.0 $\mathrm{mL}$ ethanol and $0.5 \mathrm{~mL}$ of $(5 \mathrm{~mol} / \mathrm{L}) \mathrm{FeCl}_{3}$ solution were added to the mixture. The reaction mixtures were allowed to react for different time intervals ranging from 1 to 6 minutes with an interval of 1 minute. Absorbance of the obtained complex was plotted against the reaction time The figure shows the maximum absorbance at 2 minutes which is the optimum reaction time complex formation at the given conditions (Figure 12).

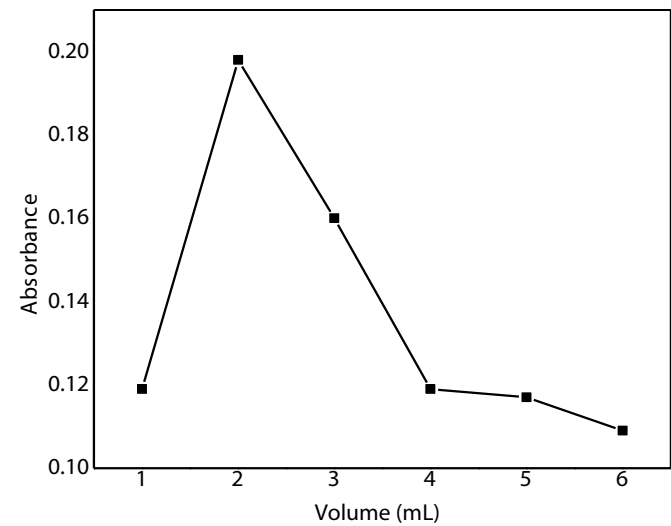

Figure 9: Effect of volume of hydrochloric acid solution on the Iron-azoxystrobin complex formation.

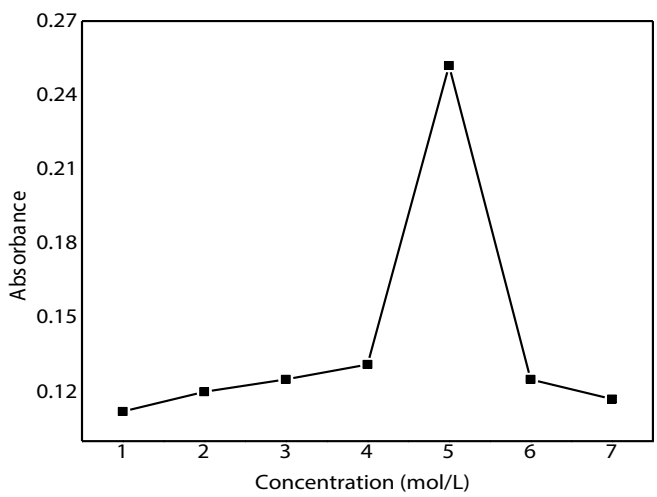

Figure 10: Effect of concentration of ferric chloride solution on Iron-azoxystrobin complex formation.

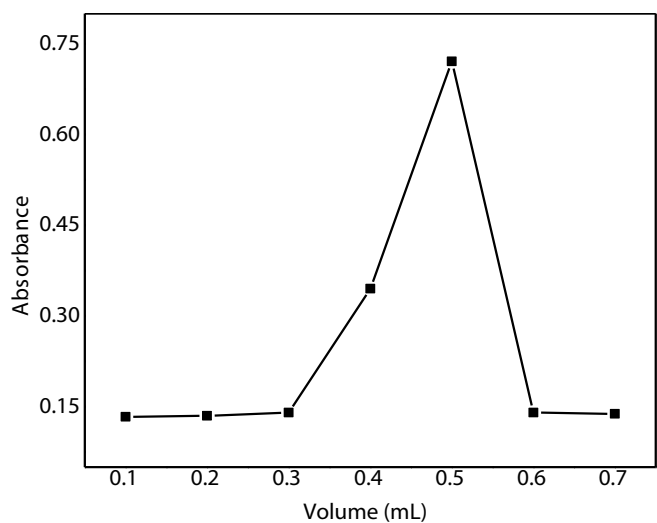

Figure 11: .Effect of volume of ferric chloride solution on complexation reaction with hydroxamic acid. 
Citation: Khan KA, Gulab H, Haider F (2018) Development of Spectrophotometric Method for the Determination of Azoxystrobin Fungicide after Derivatization. Biochem Anal Biochem 7: 353. doi: 10.4172/2161-1009.1000353

Page 5 of 6

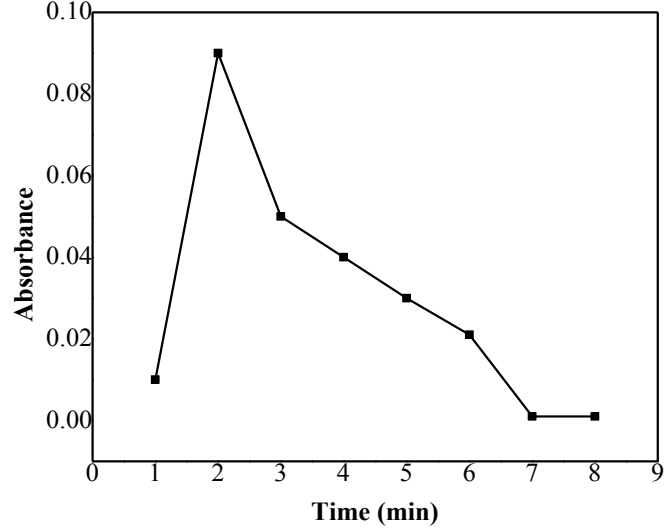

Figure 12: Effect of reaction time on Iron-azoxystrobin complex formation.

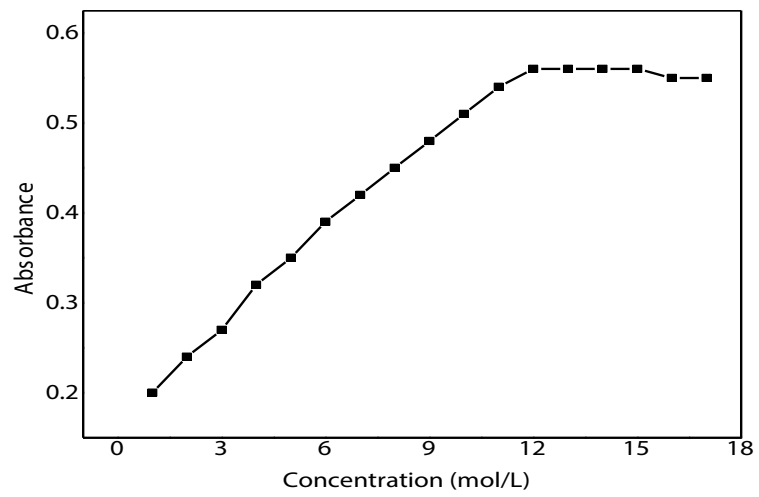

Figure 13: Verification of Beer Lambert's Law.

\begin{tabular}{|c|c|c|}
\hline S.No & Parameter & Value \\
\hline 1 & $\lambda_{\max }(\mathrm{nm})$ & 513 \\
\hline 2 & Beer's law range $\left(\mu \mathrm{g} \mathrm{mL}^{-1}\right)$ & $1.0-12$ \\
\hline 3 & Molar absorptivity $(\varepsilon)\left(\mathrm{L} \mathrm{mol}^{-1} \mathrm{~cm}^{-1}\right)$ & $4.3 \times 10^{-4}$ \\
\hline 4 & Limit of Detection $\left(\mu \mathrm{mL}^{-1}\right)$ & 0.381 \\
\hline 5 & Limit of Quantification $\left(\mu \mathrm{mL}^{-1}\right)$ & 1.27 \\
\hline 6 & Standard deviation & 0.127 \\
\hline 7 & RSD $(\%)$ & 6 \\
\hline 8 & Correlation Coefficient & 0.994 \\
\hline 9 & Slope & 0.033 \\
\hline 10 & Intercept & 0.178 \\
\hline
\end{tabular}

Table 1: Analytical Parameters for the Iron-azoxystrobin

\begin{tabular}{|c|c|c|c|}
\hline S. No. & $\boldsymbol{\mu g ~ \mathbf { ~ m } ^ { - 1 } \text { taken }}$ & $\boldsymbol{\mu g} \mathbf{~ m L}^{-1}$ found & \%Recovery $\mathbf{~ S D ~}$ \\
\hline 1 & 1 & 0.99 & $99.12 \pm 0.15$ \\
\hline 2 & 2 & 1.95 & $97.37 \pm 0.12$ \\
\hline 3 & 3 & 2.99 & $99.70 \pm 0.14$ \\
\hline
\end{tabular}

Table 2: Determination of azoxystrobin in commercial formulation.

\section{Verification of Beer's law}

For the verification of Beer's law, the absorbance was plotted against concentration of the complex (1-17 mol/L). The plot follows linear relationship up to $12 \mathrm{~mol} / \mathrm{L}$ beyond which no increase in absorbance with increase in concentration could be observed. Thus the solution obeys Beer's law in the concentration range of 1-12 mol/L and beyond this concentration deviation occurs (Figure 13).

\section{Analytical parameters}

Table 1 shows the analytical parameters for Iron-Azoxystrobin complex. The molar absorptivity of the resulting reddish wine colored Iron-Azoxystrobin complex was found to be $4.3 \times 10^{-4} \mathrm{~L} \mathrm{~mol}^{-1} \mathrm{~cm}^{-1}$. The limit of detection (LOD) and limit of quantification (LOQ) were estimated using the lowest concentration at which azoxystrobin could be detected reliably is $0.381 \mu \mathrm{g} \mathrm{mL}^{-1}$ and $1.27 \mu \mathrm{g} \mathrm{mL}^{-1}$, respectively.

\section{Percent recovery}

In order to determine the concentration of azoxystrobin in commercial formulation the percent recovery test was performed. Table 2 shows the average percent recoveries in the range of 97.37$99.70 \%$. The evaluation of analytical applications of the proposed method and was applied for azoxystrobin determination in commercial formulations. The obtained results were comparable with the labeled values [21].

\section{Conclusions}

A reddish wine colored complex can be observed by reacting the azoxystrobin with $\mathrm{FeCl}_{3}$ in the presence of hydroxylamine hydrochloride. For the utmost complex formation of Iron-azoxystrobin various parameters i.e., concentration of reagents, volume of reagents and time of reaction were optimized. Molar absorptivity, Limit of detection and Limit of quantification were calculated for the complex and recorded as $4.3 \times 10^{-4} \mathrm{~L} \mathrm{~mol}^{-1} \mathrm{~cm}^{-1}, 0.381 \mu \mathrm{g} \mathrm{mL} \mathrm{L}^{-1}$ and $1.27 \mu \mathrm{g}$ $\mathrm{mL}^{-1}$, respectively. The Beer-Lambert law was obeyed till $12 \mathrm{~mol} / \mathrm{L}$. It can be concluded from the above investigated results that the developed spectrophotometric method for the determination of azoxystrobin in the commercial drug samples is very simple, cheap, sensitive and reproducible. The easy availability of the developed method as compared to the methods reported in literature, which involved expensive and sophisticated equipment.

\section{References}

1. Russell PE (2005) J Agric Sci 143: 11-2.

2. Sobrinnho F, Lucas F, Fill TP, Filho ER, Mascaro LH, et al. (2015) Insights into electrodegradation mechanism of tebuconazole pesticide on $\mathrm{Bi}$-doped $\mathrm{PbO} 2$ electrodes. Electrochim. Acta 154: 278-286.

3. Sancho E, Villarroel MJ, Fernandez C, Andreu E, Ferrando MD, et al. (2010) Short-term exposure to sublethal tebuconazole induces physiological impairment in male zebrafish (Danio rerio). Ecotoxicol. Environ Saf 73: 370-376.

4. NR Tentu, P Tentu, TB Patrudu, Int. J. Res. Pure Appl. Chem. 1 (2012) 1-5.

5. Zhang Z, Jiang W, Jian Q, Song W, Zheng Z, et al. (2015) Residues and dissipation kinetics of triazole fungicides difenoconazole and propiconazole in wheat and soil in Chinese fields. Food Chem 168: 396-403.

6. Yang D, Wang N, Yan X, Shi J, Zhang M, et al. (2014) Microencapsulation of seed-coating tebuconazole and its effects on physiology and biochemistry of maize seedlings. Coll Surf B 114: 241-246.

7. Boudina A, Emmelin C, Baaliouamer A, Passse O, Chovelon JM, et al. (2007) Photochemical transformation of azoxystrobin in aqueous solutions. Chemosphere 68: 1280 .

8. Sopeña F, Bending GD (2013) Impacts of biochar on bioavailability of the fungicide azoxystrobin: A comparison of the effect on biodegradation rate and toxicity to the fungal community. Chemosphere 91: 1525.

9. Sundravadana S, Alice D, Samiyappana R, Kuttalam S (2008) Determination of azoxystrobin residue by UV detection high performance liquid chromatography in mango. J Braz Chem Soc19: 60 
Citation: Khan KA, Gulab H, Haider F (2018) Development of Spectrophotometric Method for the Determination of Azoxystrobin Fungicide after Derivatization. Biochem Anal Biochem 7: 353. doi: 10.4172/2161-1009.1000353

Page 6 of 6

10. Nageswara TR, Ramesh A, Parvathamma T, Suresh G (2012) Indian J Sci Res 3: 113

11. Abreu SM, Caboni P, Cabras P, Garau VL, Alves A, et al. (2006) Validation and global uncertainty of a liquid chromatographic with diode array detection method for the screening of azoxystrobin, kresoxim-methyl, trifloxystrobin, famoxadone, pyraclostrobin and fenamidone in grapes and wine. Anal Chim Acta 573: 291.

12. Polati S, Bottaro M, Frascarolo P, Gosetti F, Gianotti V, et al. (2006) HPLC-UV and HPLC-MSn multiresidue determination of amidosulfuron, azimsulfuron, nicosulfuron, rimsulfuron, thifensulfuron methyl, tribenuron methyl and azoxystrobin in surface waters. Anal Chim Acta 579:146.

13. Shi F, Zhao KH, Che J, Huang AT (2010) J Hebei Agr Sci 14: 161.

14. Giza I, Sztwiertina U (2003) Gas chromatographic determination of azoxystrobin and tifloxystrobin residues in apples. Acta Chromatogr 13: 226.

15. Abreu DMS, Correia M, Herbert P, Santos L, Alves A, et al. (2005) Screening of grapes and wine for azoxystrobin, kresoxim-methyl and trifloxystrobin fungicides by HPLC with diode array detection. Food Addit Contam 22:549.

16. Almeida C, Nogueira JMF (2012) Comparison of the selectivity of different sorbent phases for bar adsorptive microextraction-Application to trace leve analysis of fungicides in real matrices. J. Chromatogr A 7: 1265.

17. Bo HB, Chin (2007) J Chromatogr 25: 898.

18. Bo HB, Wang JH, Guo CH, Qin, Lu XY, et al. (2008) Chin J Anal Chem 36: 1471.

19. Aguilera A, Valverde A, Camacho F, Boulaid M, García-Fuentes L, et al. (2012) Effect of household processing and unit to unit variability of azoxystrobin, acrinathrin and kresoxim methyl residues in zucchini. Food Control 25:594.

20. Itoiz ES, Fantke P, Juraske R, Kounina A, Vallejo AA, et al. (2012) Deposition and residues of azoxystrobin and imidacloprid on greenhouse lettuce with implications for human consumption Chemosphere 89: 1034.

21. Wu YX, Lin F, Lin HD, Shao LZ, Jiao H (2009) J Inst Anal 28: 617. 